\title{
Rooting Response of Kiwi Cuttings by Using Different Concentration of Iba under Green House Condition
}

\author{
Babar Ali ${ }^{2 *}$, Jawad Ali ${ }^{1}$, Aziz Khan ${ }^{1}$ and Muhammad Basit Ali Shah ${ }^{3}$ \\ ${ }^{1}$ Department of Horticulture, Abdul Wali Khan University Mardan, Pakistan \\ ${ }^{2}$ Department of Horticulture, The University of Agriculture Peshawar Pakistan \\ ${ }^{3}$ Department of Plant Breeding Genetic, The University of Agriculture Peshawar, Pakistan
}

Submission: January 05, 2018; Published: May 21, 2018

"Corresponding author: Babar Ali, Department of Horticulture, The University of Agriculture Peshawar Pakistan, Email: babar.horticulture5590@gmail.com

Abstract

Kiwifruit is the most popular fruit crop now days. It is a perishable crop which has and exceeding demand due to its taste, flavor and dietary value. In the world total harvested area was 98656 (00 ha) and total yield 143170 (000ton) in 2012. Present study was conducted the period of 6th June to 6th September 2016. The study was comprised of four treatment i.e.; T1 1000ppm, T2 2000ppm, T3 3000ppm, and T4 4000ppm. The result obtained for number of days, Servival percentage, number of shoots, number of roots and roots length. These all parameter was found to be higher for T3 treatment followed by other three. Hence it can be concluded that kiwifruit initiate best cutting growth, sprouting $\%$ etc. take less time on T3 Treatment (3000ppm) and it value is highly Significant compared to other three treatment. Therefore further study should be carried to find out desired or undesired properties would be expected when mixed with other media.

Keywords: Growth performance; Hardwood cuttings; Indole-3-butyric acid; Kiwi; Rooting

\section{Introduction}

Kiwi (syn. A. delicious) is a commercial crop in New Zealand and other countries such as Chile, China and Italy [1]. Kiwi (Actinidia chinensis) also known as Chinese goose berry, monkey peach or sheep peach is a rich source of Vitamin C having higher contents than citrus and is delicious in nature. It is a large, vigorous, woody deciduous vine and can reach over 10 meters in length. It starts bearing in 3rd year while commercial bearing starts up to $5^{\text {th }}$ year. The genus contains more than 50 species distributed in the temperate and subtropical regions of the Asian continent. All member of the genus Actinidia are functionally delicious, with pistillate and staminate flowers occurring on the separate plants [1].

Kiwi plants need a full sun light, and they should also be protected from wind. Areas prone to frost (frost pockets) should be avoided. A site with a slight slope to the north is preferred, to help prevent spring frost injury and to protect plants from southwest winds in summer. Deep, well-drained sandy loam soils with added organic matter are ideal. The soil pH's of 5.0 to 6.5 are best. Raised beds ( 6 to 10 inches high) may help with soil drainage prob $\neg$ lems as good soil drainage is essential. Because kiwifruit are susceptible to heat injury, some artificial shading may be necessary. The soil should be deeply cultivated the year before planting as this will greatly help with weed control.
Irrigation water should be available. A site with easy access for honeybees is very desirable.

Kiwifruit is characterized by high amount of vitamin C with A. delicious containing $140 \mathrm{mg} 100-1 \mathrm{~g}$ of pulp. Minerals are also high, especially potassium and magnesium as well as copper, zinc and manganese. Fruit is consumed fresh within 1-6 months after harvest. However, kiwifruit is also used in food industry, such as jams, juices and syrups [2].

It is currently accepted that the consumption of kiwifruit has a preventive effect against certain cancers and cardiovascular diseases. Many different cancers, especially cancers of the digestive system (mainly stomach cancer), lung, and liver, have been treated with kiwifruit prescriptions due to its cytotoxic and antioxidant activities. Therefore, the beneficial effects of fruits and vegetables may be related to the antioxidant properties. It is currently accepted that the consumption of kiwifruit has a preventive effect against certain cancers and cardiovascular diseases. Many different cancers, especially cancers of the digestive system (mainly stomach cancer), lung, and liver, have been treated with kiwifruit prescriptions due to its cytoxic and antioxidant activities. Therefore, the beneficial effects of fruits and vegetables may be related to the antioxidant properties. 
The kiwifruit may be propagated by various methods such as grafting seedlings, stem cuttings, root cuttings and tissue culture. The production of kiwifruit more quickly and cheaply would be of considerable commercial value, and growing cuttings on their own roots could achieve this purpose by eliminating the need for rootstocks as well as for budding and grafting. Previous researches have shown that kiwifruit cuttings are characterized by a variable rooting ability [3]. Kiwi fruit is propagated by cuttings with different treatments, among which the application for plant growth regulators (PGRs) is one of the most common practices [4].

The greatest success was achieved in plants such as kiwi fruits, figs and apples through IBA treatment, which is necessary for hardwood and softwood cuttings [5].

Kiwi fruit can be propagated from seed or hard wood cutting but seedling are not recommended because of it's dioeciously nature as the sex is unknown until flowers are produced. Rana et al. [3] treated Kiwi cuttings with 500ppm IBA in spring season and found 57\% rooting response. Abdel-Hussain and Salman 1988 concluded that wounding plus IBA treatment at $4000 \mathrm{ppm}$ gave the highest rooting percentage and greatest number of roots, root length and individual root weight of cuttings. Daud et al. 1989 reported that dipping the cutting in 2000, 3000 and $4000 \mathrm{ppm}$ IBA increased the number of roots. The effect increased with increasing IBA concentration. Kiwi cuttings are hard to root, therefore, the present study was initiated to study the effect of different concentrations of IBA on the performance of kiwi fruit cuttings [6-13].

\section{Objectives}

a. To plan and coordinate the floriculture research activities at National level and establish liaison with international research institutions.

b. Germplasm screening of flowers for development of new potato varieties.

c. Standardization of production technologies for different ecological zones of the country.

d. Strength certified flower seed production.

e. To improve the income of resource poor farmers in flowers based farming system.

\section{Material and Methods}

The present experiment was conducted in the green house of Directorate of Fruit Department of Horticultural Research and development, NARC Islamabad, during June-July (2016). Cuttings of Kiwi were collected from HRI department. The study was conducted to evaluate the effect of different concentration of Indole Butyric Acid (IBA) (1000ppm, 2000ppm, 3000ppm and $4000 \mathrm{ppm}$ ) to check the rooting percentage of peach cuttings The agro-climate of Islamabad region falls under semi-arid zone and comprises of sub-tropical climate. Plants were planted in pots under green house and cover with the polythene bags to maintain the humidity. Planting of cuttings were done during Aug-2016. IBA concentration applied according to the following ratios.

Control: T0 No IBA concentration was applied.

T1 1000ppm

T2 2000ppm

T3 3000ppm

T4 4000ppm

\section{Geographical location}

The experiment was carried out at the experiment field of Directorate of fruit, Department of Horticultural Research and development (DHR\&D), NARC Islamabad during June-July 2016. The experimental site is located at longitude $73.08^{\circ}$ east and latitude $33.42^{\circ}$ north on the global scale. Elevation of site was 683 MSL (Mean Sea Level). The annual rainfall in this area is about $1000 \mathrm{~mm}$.
Experimental Material
a. Cultivar (Hayward)
b. Prunning scissor
c. Growth Regulators
d. Pots
e. Sand

\section{Polythene Bags}

\section{Treatments}

The experiment will be designed to study the rooting response of Kiwi cutting under green house condition using IBA 1000ppm, 2000ppm, 3000ppm and 4000ppm.

\section{Cultivar Hayward}

Growth Regulator IBA 1000ppm, 2000ppm, 3000ppm and 4000ppm.

Data to be Recorded

The data will be recorded on the following parameters.

a. Rooting percentage.

b. No. of roots per cutting.

c. Average root length per cutting.

d. Survival percentage.

\section{Experimental Procedure}

Cutting pots was covered with polythene bags to keep the humidity inside the green house. The percentage of rooted 
cuttings, Number of roots per cutting and average root length per cutting will be recorded 45 days after planting.

\section{Data to be Recorded}

The data were recorded on the following parameters.
a. Sprouting percentage
b. Number of leaves per cutting
c. Shoot percentage
d. Root length
e. Number of roots per cutting.

\section{Chemical are Used}

Use of electronic weight balance: Weighting of IBA was done by using Electronic Weight balance. IBA was prepared from Chalk powder. IBA was applied to Cuttings of Kiwi at different concentrations (1000 ppm, $2000 \mathrm{ppm}, 3000 \mathrm{ppm}$ and 4000 ppm).

\section{Survival Percentage}

It was observed that maximum survival percentage was recorded for IBA 3000ppm (81.34) and the minimum survival percentage was observed in control treatment 19.00 .

\section{Number of shoots/cuttings}

It was observed that maximum number of shoots recorded for IBA 3000ppm (7.00) and the minimum number of shoots was observed in control treatment 1.00 .

\section{Number of Roots/ Cuttings}

It was observed that maximum number of roots recorded for IBA $3000(70.01)$ and the minimum number of roots was observed in control treatment 13.05.

\section{Root length}

It was observed that maximum root length recorded for IBA 3000 (19.11) and the minimum root length was observed in control treatment 4.51 (Figure 1 \& 2).

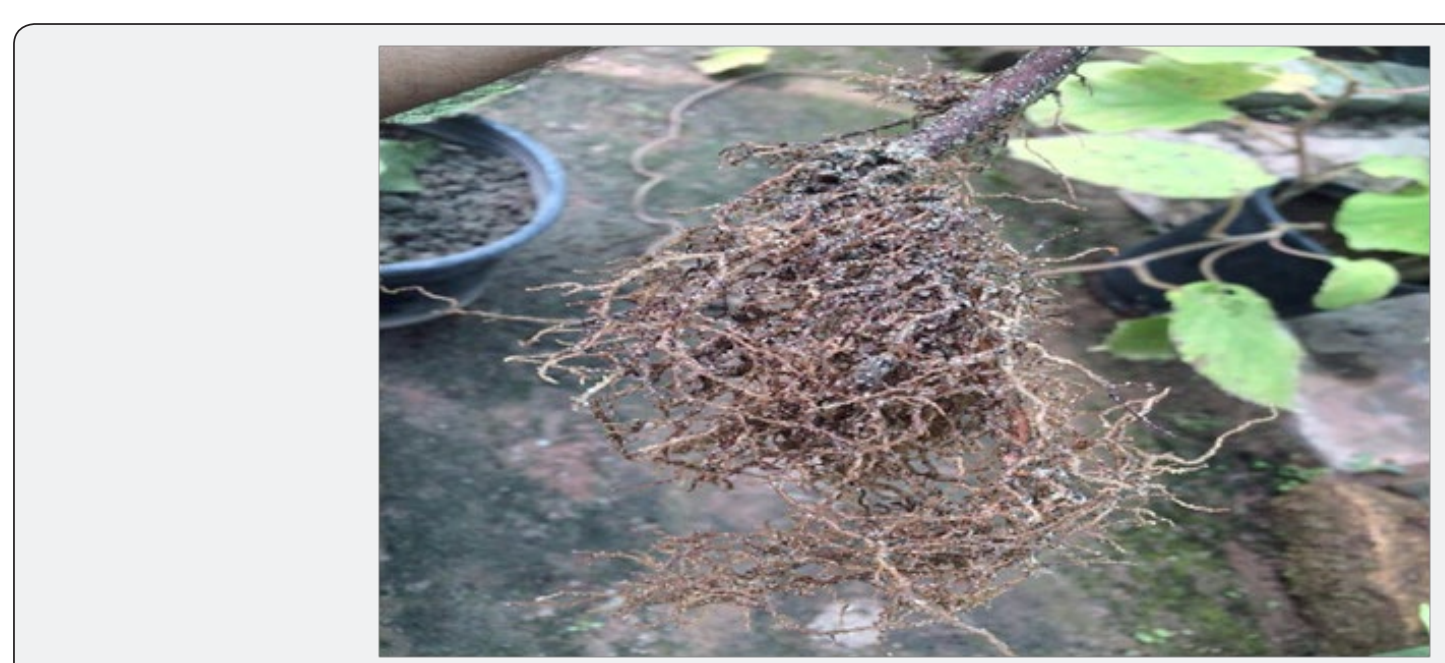

Figure 1.

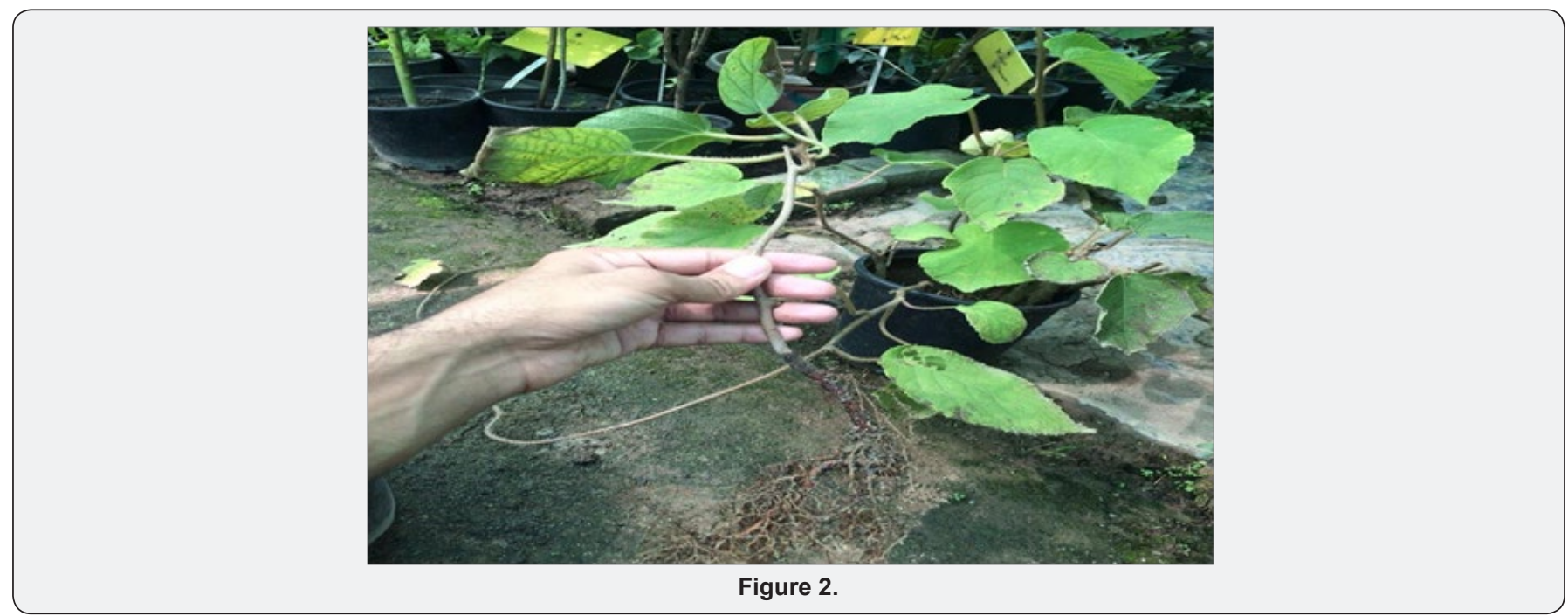




\section{References}

1. Ferguson AR (1990) The genus Actinidia. In: Warrington IJ, Weston GC (Eds.), Kiwifruit: Science and management. The New Zealand Society of Horticultural Science, Auckland, New Zealand.

2. Rugini E, Gutierrez-Pesce P (2003) Micropropagation of kiwifruit (Actinidia ssp). In: Jain SM, Ishii K (Eds.), Micropropagation of Woody Trees and Fruits. Kluwer Academic Publishers, Netherlands, pp: $647-$ 669.

3. Rana HS, Raba VS, Bhardwaj DR (1999) Vegetative multiplication of kiwifruit (Actinidia deliciosa) through dormant cuttings. Annals of Forestry 7(1): 56-59.

4. Polat AA, Kamiloglu O (2007) Experiment on propagation with cutting of Quince-A and BA-29 rootstocks and on budding with loquat cultivar. Turkey 5th National Horticulture Congress 1: 169-173.

5. Ercisli S, Esitken A, Cangi R, Sahin F (2004) Adventitious root formation of kiwifruit in relation to sampling date, IBA and agro bacterium Rubi inoculation. Plant Growth Regulation 41(2): 133-137.

6. Ding SL, Zhu XZ, Yu HM (1997) China fruits. pp. 27-29.
7. Gjeloshi G, Thomai T, Susaj E (2014) Online International Interdisciplinary Research Journal, India. Online International Interdisciplinary Research Journal 4(Special Issue): 98-102.

8. Glare TR, Gartrell BD, Brookes JJ, Perrott JK (2014) American Association of Avian Pathologists, Athens, USA. Avian Diseases 58(1): 16-24.

9. Kornova K, Popov S, Acad M (2010) Popov institute of plant Physiology, Bulgarain Academy of Science, Sofia, Bulgaria. General and applied plant physiology 36(1/2): 69-72

10. One EO, Rodrigues JD, Pinho SZ, de (1995) Phyton (Buenos Aires). 57(2): 137-147

11. Recio-Rodriguez JI, Gomez-Marcos MA, Patino-Alonso MC, Puigdomenech E, Notario-Pacheco B, et al. (2015) BioMed Central Ltd. London, UK. Nutrition Journal 14(97).

12.Zenginbal H, Ozcan M Ondokuz Malyis University, Ziraat Fakultesi, Samsun, Turkey. Anadolu Tarim Bilimleri Dergisi 28(3): 115-125.

13. Zenginbal H, Ozcan M (2014) Ondokuz Mayis Universitesi, Ziraat Fakultesi, Samsun, Turkey. Anadolu Tarim Bilimleri Dergisi 29(1): 1-11.

\section{Your next submission with Juniper Publishers will reach you the below assets}

- Quality Editorial service

- Swift Peer Review

- Reprints availability

- E-prints Service

- Manuscript Podcast for convenient understanding

- Global attainment for your research

- Manuscript accessibility in different formats

( Pdf, E-pub, Full Text, Audio)

- Unceasing customer service

Track the below URL for one-step submission https://juniperpublishers.com/online-submission.php 